IJMS 16 (1), 1-30 (2009)

\title{
PEMBANGUNAN JADUAL INPUT-OUTPUT WILAYAH DAN ANALISIS KE ATAS STRUKTUR INDUSTRI SELANGOR
}

\author{
MOHD YUSOF SAARI \\ ZAKARIAH ABDUL RASHID \\ Fakulti Ekonomi dan Pengurusan \\ Universiti Putra Malaysia
}

\begin{abstract}
ABSTRAK
Artikel ini membentangkan hasil kajian ke atas pembangunan jadual inputoutput negeri Selangor yang dianggar dengan menggunakan teknik RAS pada tahun 2000. Dengan menggunakan andaian kesamaan penggunaan input dan teknologi pengeluaran antara Selangor dan Malaysia, struktur aliran antara industri Selangor dianggar berasaskan struktur aliran antara industri nasional. Jadual input-output yang dianggar kemudiannya digunakan untuk menjalankan analisis ke atas struktur pengeluaran industri Selangor. Hasil kajian mendapati Selangor memiliki struktur pengeluaran industri yang sederhana dan terlalu bergantung kepada import dan eksport. Analisis ke atas kaitan antara industri mendapati sektor pembuatan, perlombongan dan kuari, dan perkhidmatan kerajaan merupakan sektor-sektor strategik di Selangor yang dapat memberi impak besar ke atas pembangunan ekonomi negeri.
\end{abstract}

\begin{abstract}
Purpose - This paper attempts to estimate a regional input-output table for Selangor for 2000. Then, the regional input-output table is used to analyse the production structures in Selangor.

Design/Methodology/Approach - The regional input-output table for Selangor is estimated by applying the RAS tehchique. Accordingly, under the homogeneity assumption of production structures and technologies between Selangor and Malaysia, the structure of Selangor's inter-industry is estimated based on the structure of national inter-industry transactions.
\end{abstract}

Findings - Results showed that Selangor has modest production structure and highly dependent on imports and exports. The inter-industry linkages analysis 
indicated that manufacturing, mining and quarrying, and government service sectors are the key sectors in Selangor, where these sectors have potential to stimulate growth in the economy.

Originality/Value - This paper is a pioneer study for the construction of a regional input-output table for Malaysia, especially for Selangor, by using a partial survey approach. For the purpose of planning, the regional input-output table is an important economic tool because it compiles the whole demand and supply of production sectors in an economy.

Keywords - Regional input-output, Linkages, RAS technique, Selangor.

Paper type - Research paper

\section{PENGENALAN}

Perangkaan menunjukkan ekonomi negeri Selangor merupakan penyumbang utama kepada pertumbuhan ekonomi Malaysia. Pada tahun 2000 dan 2005, negeri Selangor telah menyumbang lebih 21\% kepada Keluaran Dalam Negara Kasar (KDNK) negara seperti yang ditunjukkan pada Jadual 1. Sepanjang tempoh Rancangan Malaysia Kelapan (2001-2005), ekonomi negeri Selangor telah bertumbuh pada kadar purata $7.7 \%$ setahun dan menjadi penyumbang yang tertinggi kepada KDNK negara berbanding negeri-negeri lain. Sumbangan yang besar ini juga membawa implikasi bahawa Selangor adalah negeri termaju di Malaysia berbanding dengan negeri-negeri lain di bawah kumpulan negeri telah membangun.

Di samping itu, petunjuk guna tenaga juga menunjukkan ekonomi Selangor menyerap kadar guna tenaga tertinggi berbanding negerinegeri lain. Penggunaan guna tenaga negeri telah meningkat daripada 1.6 juta pada tahun 2000 kepada hampir 2 juta pada tahun 2005 (Jadual 1). Kadar pengangguran Selangor juga telah merundum dari 1.9\% pada tahun 2000 kepada 1.7\% pada tahun 2005, hasil penggunaan guna tenaga yang meningkat kesan daripada kemakmuran dan pertumbuhan ekonomi. Eksport barangan dan perkhidmatan negeri pula telah menyumbang sebanyak 97\% kepada KDNK negeri (Unit Perancang Ekonomi Negeri, 2004). Perbandingan menunjukkan peratusan sumbangan ini adalah bersamaan dengan jumlah eksport barangan dan perkhidmatan Malaysia terhadap KDNK negara. Kemakmuran ekonomi yang dinikmati oleh Selangor adalah hasil daripada pertumbuhan ekonomi yang memberangsangkan. 


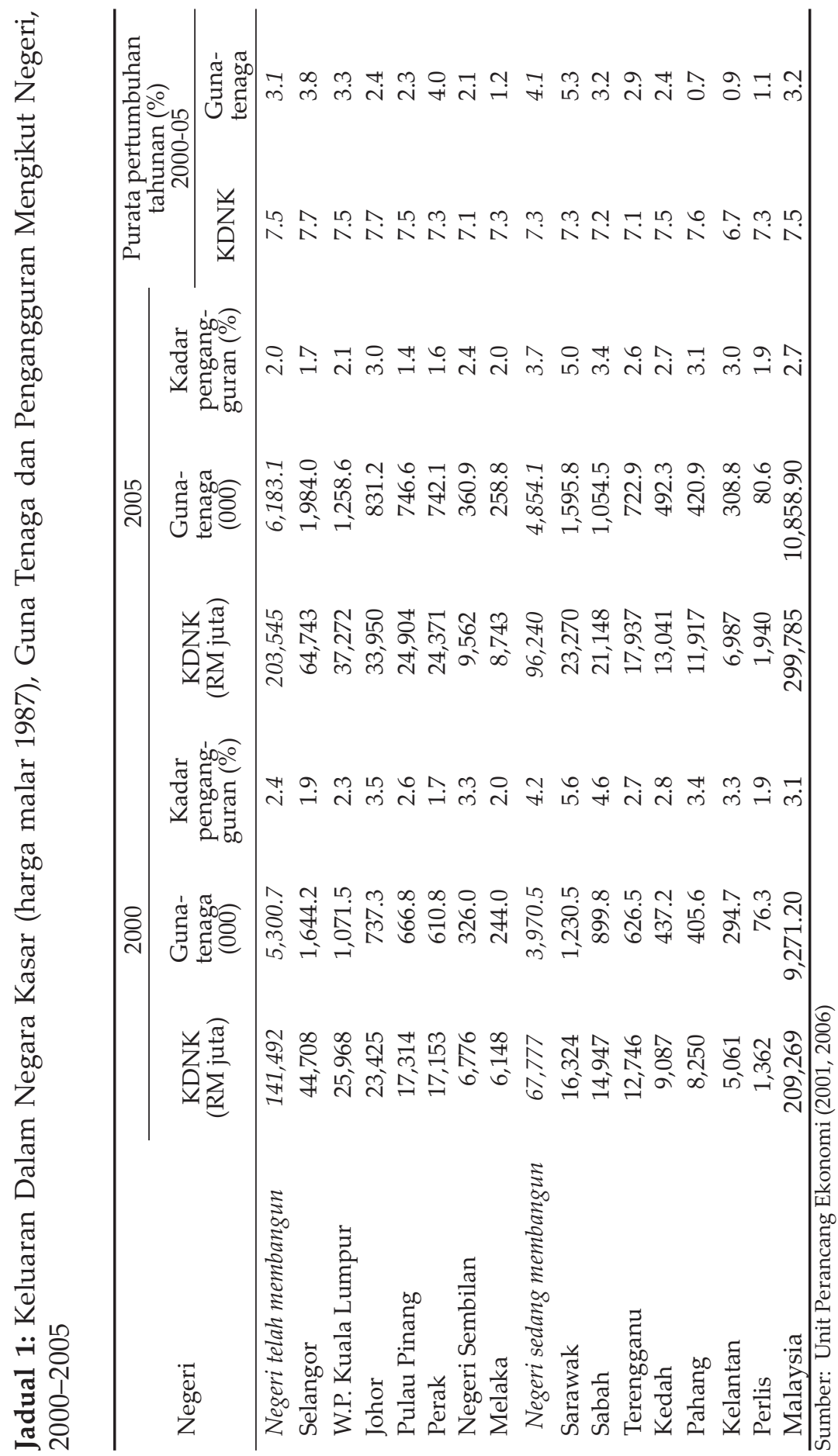


Pertumbuhan ekonomi yang memberangsangkan ini sebahagian besarnya disumbangkan oleh sektor perindustrian dengan kadar sumbangan KDNK sebanyak 59\% atau RM 36.5 bilion pada tahun 2004. Sumbangan sektor pembuatan yang signifikan ini didorong oleh permintaan tinggi ke atas keluaran elektrik dan elektronik, di tambah dengan peningkatan pelaburan swasta. Ini diikuti oleh sektor perkhidmatan yang menyumbang sebanyak 38\% (RM 23.4 bilion) terhadap KDNK negeri. Walaupun sektor pertanian hanya menyumbang sebanyak 3\% (RM 1.3 bilion) sahaja kepada KDNK negeri, sektor ini memainkan peranan penting sebagai pembekal kepada pengeluaran makanan dan bahan mentah untuk industri asas tani negeri.

Negeri Selangor dijangka akan terus membangun dengan pesatnya, berkembang pada kadar purata $6.4 \%$ setahun mengikut unjuran dalam Rancangan Malaysia Kesembilan (2006-10). Pembangunan sektor pembuatan akan terus diperkukuhkan lagi dengan penyediaan iklim pelaburanyangkondusifbagisektorswastauntuk melabur dalam industri berteknologi tinggi, mempelbagaikan keluaran eksport dan pasaran serta membangunkan industri sokongan. Begitu juga, kepentingan dan sumbangan sektor pertanian dan perkhidmatan kepada pembangunan akan terus diperkasa. Malahan aktiviti-aktiviti ekonomi di bawah sektor pertanian dan perkhidmatan akan dipergiatkan lagi terutamanya dalam bidang bio-industri berteknologi tinggi dan perkhidmatan pemborongan dan peruncitan, dan kewangan yang berpotensi besar menjana ekonomi negeri Selangor dan seterusnya ekonomi negara.

Tentunya dalam merancang pertumbuhan ekonomi di peringkat negeri, penggubal dasar perlu mendapat maklumat terperinci mengenai potensi industri yang terdapat di dalam ekonomi yang perlu diberi perhatian. Tambahan pula disebabkan setiap industri dalam ekonomi berinteraksi antara satu sama lain, maklumat kaitan antara industri amat penting agar sebarang usaha pembangunan ekonomi dapat dinikmati oleh keseluruhan industri. Memandangkan maklumat-maklumat pada peringkat industri penting dalam perancangan ekonomi, sesebuah negeri perlu memiliki jadual input-output. Jadual input-output merupakan sebuah matrik yang mengambarkan aliran permintaan dan penawaran bagi setiap sektor dalam ekonomi. Ianya sangat berguna dalam membuat perancangan dan penilaian impak ke atas ekonomi Selangor dalam usaha membangunkan ekonomi negeri. Justeru itu, dengan usaha sama Unit Perancang Ekonomi Negeri Selangor (UPENS), artikel ini membentangkan hasil kajian ke atas pembangunan jadual input-output 
Selangor yang dianggar menggunakan pendekatan separa-tinjauan, iaitu aplikasi teknik RAS. Teknik RAS hanya digunakan untuk menganggar aliran antara industri sahaja manakala aliran-aliran lain di dalam jadual input-output disusun berdasarkan data sebenar pada tahun tersebut. Penganggaran dilakukan dengan mengandaikan struktur pengeluaran dan teknologi industri di antara Selangor dan Malaysia adalah sama. Pada penelitian penyelidik, pembangunan jadual input-output Selangor merupakan usaha awal ke atas pembangunan jadual input-output wilayah di Malaysia.

Artikel ini disusun seperti berikut; bahagian 2 memperinci kerangka jadual input-output negeri yang dibina; bahagian 3 pula membincang secara terperinci teknik RAS yang digunakan untuk menganggar jadual input-output berserta sumber data yang digunakan; bahagian 4 membentangkan dapatan kajian yang diperolehi; dan bahagian 5 membuat ringkasan keseluruhan kertas ini.

\section{KERANGKA JADUAL INPUT-OUTPUT SELANGOR}

Aspek paling penting dalam pembinaan jadual input-output Selangor ialah penentuan dimensi jadual input-output itu sendiri. Asas utama yang digunakan sebagai penentu kepada dimensi jadual input-output ialah maklumat data output, permintaan akhir dan input primer mengikut industri di Selangor. Memandangkan terdapat beberapa kekangan untuk memperoleh data-data di peringkat industri terutamanya industri-industri di bawah sektor pertanian dan perkhidmatan, kami telah menetapkan dimensi jadual input-output Selangor kepada 58 industri. Daripada jumlah tersebut, 53\% atau 31 industri adalah terdiri daripada sektor pembuatan dan selebihnya adalah sektor pertanian, perkhidmatan kerajaan dan perkhidmatan swasta.

Jadual input-output Selangor yang dibentuk mempunyai empat sukuan utama seperti yang ditunjukkan oleh Jadual 2. Sukuan-sukuan ini terdiri daripada (i) sukuan I-sukuan permintaan dan penawaran antara industri, (ii) sukuan II - permintaan akhir, (iii) sukuan III - aliran input primer dan (iv) sukuan IV - pindahan bukan pasaran. Sukuan I menggambarkan penawaran dan permintaan barangan dan perkhidmatan di antara industri. Terdapat 58 industri telah dikenal pasti sebagai penjana utama ekonomi negeri. Sukuan ini diwakili oleh sub-matrik (58 x 58), bermula daripada industri pertanian sehingga perkhidmatan kerajaan. Sukuan 
II menggambarkan aliran output industri yang digunakan oleh sektor permintaan akhir yang merangkumi perbelanjaan swasta, penggunaan kerajaan, perubahan stok, pengumpulan modal tetap kasar dan eksport. Matrik yang diwakili oleh sukuan permintaan akhir ialah $(58 \times 5)$.

Sukuan III dan IV pula melibatkan aliran penggunaan input primer oleh industri dan sektor permintaan akhir. Sukuan III menunjukkan aliran input primer yang digunakan dalam proses pengeluaran barangan dan perkhidmatan oleh sektor-sektor pengeluaran. Input-input ini merupakan sebahagian daripada kos pengeluaran yang terdiri daripada nilai ditambah yang dibayar kepada faktor-faktor pengeluaran, bahan mentah yang diimport dan cukai ke atas komoditi yang dibeli sama ada domestik mahupun yang diimport. Sukuan ini diwakili oleh sub-matrik (4 x 58). Sukuan terakhir pula terdiri daripada aliran input primer secara langsung yang diguna oleh sektor-sektor permintaan akhir. Sukuan ini diwakili oleh sub-matrik $(4 \times 5)$.

Jadual 2: Struktur Jadual Input-Output Selangor

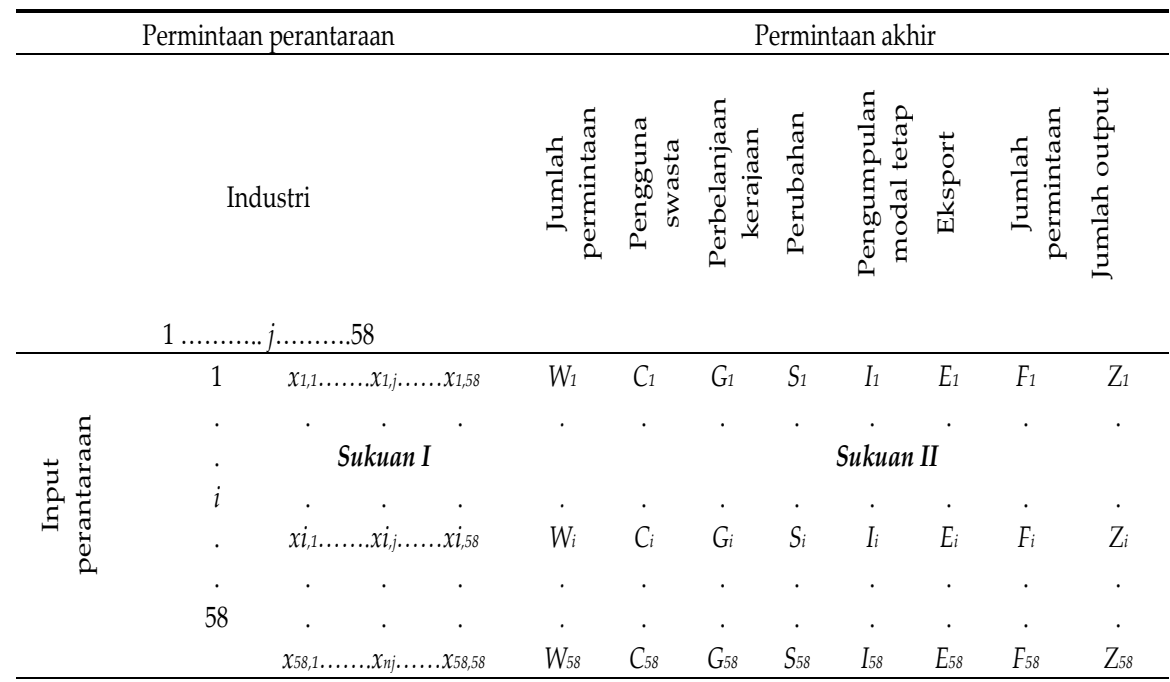

Input $\quad U_{1} \ldots U_{j} \ldots U_{58}$

perantaraan

\begin{tabular}{|c|c|c|c|c|c|c|c|}
\hline \multirow{3}{*}{ 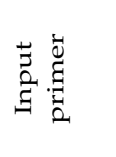 } & Sukuan III & \multicolumn{6}{|c|}{ Sukuan IV } \\
\hline & $V_{1,1} \ldots . V_{1, j} \ldots \ldots . . V_{1,58}$ & $V_{1, C}$ & $V_{1, G}$ & $V_{1, S}$ & $V_{1, I}$ & $V_{1, E}$ & \\
\hline & $V_{4,1} \ldots \ldots V_{4, j} \ldots \ldots V_{4,58}$ & $V_{4, \mathrm{C}}$ & $V_{4, G}$ & $V_{4, S}$ & $V_{4, I}$ & $V_{4, E}$ & \\
\hline $\begin{array}{c}\text { Jumlah } \\
\text { input }\end{array}$ & $X_{1} \ldots \ldots X_{j} \ldots \ldots X_{58}$ & $C$ & G & $S$ & $I$ & $E$ & $F$ \\
\hline
\end{tabular}


Penyusunan aliran eksport dan import merupakan komponen utama yang membezakan di antara jadual input-output wilayah dan nasional. Di dalam jadual input-output wilayah, kedua-dua urus niaga ini perlu dibezakan di antara dua kategori iaitu urusniaga yang berlaku di antara wilayah dan luar negara. Eksport misalnya, perlu dibezakan di antara barangan dan perkhidmatan yang dieksport ke luar negara dan yang dieksport ke wilayah lain dalam sesebuah negara. Walau bagaimanapun, di dalam penyusunan jadual input-output Selangor ini, kami tidak dapat menganggar urus niaga perdagangan (eksport dan import) antara negeri kerana ketiadaan data yang mewakili urus niaga tersebut. Tambahan lagi, soal selidik yang digunakan terhadap penyiasatan industri juga tidak mempunyai maklumat tersebut.

\section{TEKNIK PENGANGGARAN DAN DATA}

Kekangan utama ke atas analisis ekonomi input-output wilayah ialah menganggar jadual input-output wilayah dengan menggunakan pendekatan tinjauan. Melalui pendekatan ini, jadual input-output dibina berasaskan penyiasatan, pengumpulan dan penyusunan data dengan mengambil kira penawaran dan penggunaan industri. Walaupun pendekatan tinjauan merupakan teknik penganggaran yang terbaik, ianya melibatkan kos penyediaan yang tinggi dan memakan masa yang lama untuk menyiapkannya. Akibat daripada kekangan ini, teknik bukan-tinjauan diperkenalkan sebagai pilihan kepada teknik tinjauan. Antara teknik bukan-tinjauan yang dipratik ialah pengagihan lokasi mudah (simple location quotient), pengagihan industri-silang (cross-industry quotient) dan penyesuaian penawaran-permintaan (supply-demand adjustment). Kaedah ini membentuk jadual input-output wilayah berasaskan jadual input-output nasional yang dianggar secara simetri dengan mengubahsuai jadual mengunakan petunjuk ekonomi wilayah seperti output, guna tenaga dan nilai ditambah. Demikian juga, walaupun teknik bukan-tinjauan menjimatkan kos dan hanya memerlukan jangka masa singkat untuk menyiapkan jadual inputoutput, namun ralat penganggaran cenderung melebar.

Sebagai langkah alternatif kepada teknik tinjauan dan bukantinjauan, teknik RAS yang menggunakan pendekatan separa-tinjauan dipratikkan. Sejak diperkenalkan oleh Stone (1963), teknik RAS menjadi pilihan kebanyakkan penganalisis untuk menganggar jadual inputoutput wilayah, antaranya, Czamanski dan Malizia (1969), Sawyer dan Miller (1983) dan Dewhurst (1992). Malahan, kajian perintis oleh 
Morrison dan Smith (1974) menunjukkan teknik RAS menghasilkan keputusan yang lebih baik berbanding dengan 7 teknik bukan-tinjauan yang lain. Bersandarkan kepada bukti empirikal tersebut, penyelidik telah mengaplikasikan sepenuhnya teknik RAS bagi menganggar jadual input-output Selangor. Keseluruhannya, teknik ini lebih efisyen berbanding teknik bukan-tinjauan kerana kualiti data yang digunakan adalah lebih baik serta komprehensif. Malah, kami juga telah mencuba mengaplikasi teknik pengagihan lokasi mudah ke atas data Selangor dan Malaysia, dan keputusan yang diperolehi adalah tidak realistik.

Teknik RAS hanya menganggar sukuan I jadual input-output manakala data untuk sukuan II, sukuan III dan sukuan IV diperoleh hasil daripada tinjauan yang dilakukan pada tahun tersebut. Data-data yang diperoleh daripada tinjauan seperti Penyiasatan Industri dan Perangkaan Perdagangan Luar Negeri akan digunakan untuk melengkapkan Sukuan II, III dan IV. Teknik RAS menganggar sukuan I (atau dikenali juga sebagai matrik pekali input) jadual input-output Selangor berasaskan struktur jadual input-output nasional. Teknik ini menganggar aliran urus niaga antara industri Selangor (Sukuan I) secara simetri dengan mengubahsuai aliran urus niaga antara industri nasional apabila diberi jumlah input perantaraan dan permintaan perantaraan Selangor.

Teknik ini mengandaikan struktur penggunaan input dan teknologi pengeluaran Selangor adalah bersamaan dengan struktur pengeluaran nasional. Andaian ini diterima umum kerana secara asasnya, struktur pengeluaran industri yang mengeluarkan komoditi yang homogenous cenderung memiliki struktur pengeluaran yang sama walaupun berbeza lokasi kedudukan. Spesifiknya, andaian ini merujuk kepada kesamaan gelagat penggunaan input-input oleh industri yang mengeluarkan komoditi yang homogenous di Selangor dan nasional. Contohnya, penggunaan input-input seperti keluaran logam, bahan kimia, dan elektrik dan gas untuk industri keluaran elektronik sama ada beroperasi di Selangor atau di negeri-negeri lain mempunyai kecenderungan yang serupa. Malah, jika industri keluaran elektronik didominasikan oleh Selangor maka anggaran dijangka akan lebih efisyen.

Justifikasi utama terhadap andaian ini ialah berdasarkan bukti bahawa wujudnya kecenderungan sistem ekonomi moden memiliki struktur asas pengeluaran yang serupa (Simpson dan Tsukui, 1965). Malahan, Harrigan dan rakan-rakan (1980) dalam kajian perbandingan ke atas ekonomi United Kingdom dan Scotland mendapati kedua-duanya memiliki ciri ekonomi moden. Walau bagaimanapun, teknik ini mungkin 
tidak dapat memberi penganggaran secara tepat sepenuhnya disebabkan oleh andaian yang digunakan. Namun, teknik ini merupakan pilihan teknik alternatif terbaik kepada teknik tinjauan dan bukan-tinjauan. Sensitiviti dan ralat yang dihasilkan oleh teknik RAS hanya boleh dikaji jika kita memiliki jadual input-output yang dianggar berdasarkan teknik tinjauan.

Kaedah operasi RAS dapat diperjelaskan dengan mengunakan persamaan berikut (sila rujuk Saari \& Zakariah, 2006 untuk pemahaman lanjut teknik ini);

$$
R \quad{ }_{0} A \quad S={ }_{1} A
$$

di mana $R$ and $S$ adalah matrik pepenjuru, dan ${ }_{0} A$ dan ${ }_{1} A$ ialah masingmasing matrik pekali input nasional dan Selangor. Matrik pepenjuru $R$ juga dikenali sebagai faktor penggantian yang berfungsi untuk melaras lebihan baris matrik. Matrik pepenjuru $S$ pula dikenali sebagai faktor fakbrik yang berfungsi untuk melaras lebihan lajur matrik.

Matrik ${ }_{1} A$ iaitu matrik pekali input Selangor yang dibentuk hasil daripada pendaraban pre dan post matrik $A$ dengan matrik pepenjuru. Ringkasnya, setiap elemen ${ }_{1} a_{i j}$ matrik ${ }_{1} A$ diperolehi daripada elemen ${ }_{0} a_{i j}$ matrik ${ }_{0} A$ seperti persamaan berikut;

$$
{ }_{1} a_{i j}=r_{i} \quad a_{i j} s_{j}
$$

Oleh kerana persamaan (2) menunjukkan semua elemen matrik $A$ dan ${ }_{1} A$ adalah sama, maka dimensi kedua-dua matrik ini juga turut sama. Setiap elemen $R$ mesti bersamaan dengan bilangan baris ${ }_{0} A\left(\right.$ dan $\left.{ }_{1} A\right)$, manakala bilangan lajur ${ }_{0} A\left(\operatorname{dan}_{1} A\right)$ penentu bilangan elemen $S$. Dalam teknik RAS, setiap baris elemen $R$ dan ${ }_{1} a_{i j}$ dibentuk dengan mendarabkan setiap elemen baris $i$ matrik $A$ dengan faktor $R$ yang sama. Apabila semua operasi baris untuk matrik ${ }_{0} A$ selesai, ia akan menghasilkan matrik B;

$$
B=R A
$$

ataupun bersamaan

$$
b_{i j}=r_{i 0} a_{i j}
$$

Proses terakhir membentuk matrik ${ }_{1} A$ ialah mendarabkan setiap elemen lajur $j$ matrik $B$ dengan setiap elemen lajur $j$ faktor $S$. Hasil pendaraban ini akan menghasilkan matrik $B S$ 


$$
B S=R{ }_{0} A \quad S={ }_{1} A
$$

di mana,

$$
{ }_{1} a_{i j}=c_{i j} s_{j}=r_{i 0} a_{i j} s_{j}
$$

Andaikan terdapat tiga sektor, elemen matrik pepenjuru $R$ dan $S$ dapat diwakilkan di dalam persamaan matrik berikut:

$$
\left(\begin{array}{ccc}
r_{1} & 0 & 0 \\
0 & r_{2} & 0 \\
0 & 0 & r_{3}
\end{array}\right) \quad \text { dan }\left(\begin{array}{ccc}
s_{1} & 0 & 0 \\
0 & s_{2} & 0 \\
0 & 0 & s_{3}
\end{array}\right)
$$

Dengan mengaplikasi persamaan (6), matrik aliran urusniaga Selangor dapat diringkaskan seperti persamaan (8) berikut;

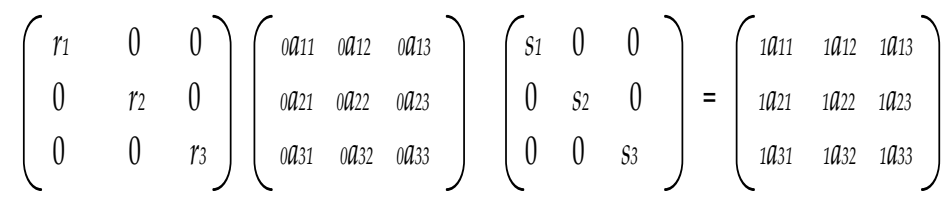

atau bersamaan dengan

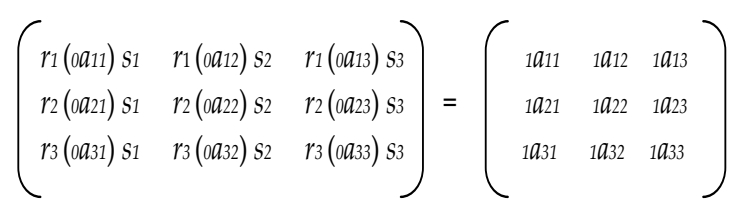

\section{Sumber Data}

Jadual input-output Selangor dianggar pada tahun asas 2000, iaitu konsisten dengan terbitan jadual input-output nasional. Justeru itu, keseluruhan data eksogenous yang digunakan untuk tujuan penganggaran perlulah mempunyai tahun rujukan yang sama. Data utama yang diperlukan dalam kajian ini adalah data-data bagi sukuan input primer, permintaan akhir dan output. Data-data tersebut diperoleh daripada pelbagai sumber yang merangkumi data yang diterbitkan mahupun yang tidak diterbitkan. Kebanyakkan data-data ini dibekalkan oleh Jabatan Perangkaan dan UPENS. Oleh kerana jadual input-output dibina berdasarkan pertubuhan industri, iaitu Piawaian 
Klasifikasi Industri Malaysia (MSIC) pada peringkat 5-digit, maka data yang dikumpul perlulah bersesuaian dengan klasifikasi ini. Jika terdapat perbezaan klasifikasi di antara data yang diperolehi, pemadanan data dilakukan bagi memastikan data yang digunakan adalah konsisten.

Untuk sukuan permintaan akhir, data perbelanjaan swasta diperoleh daripada Tinjauan Perbelanjaan Isirumah (HES). Data mentah yang diperolehi daripada HES kemudiannya dianalisis dan dipadankan mengikut klasifikasi input-output. Sementara itu, data perbelanjaan kerajaan negeri Selangor pula dibekalkan oleh UPENS. Bagi data perubahan inventori dan pengumpulan modal tetap kasar, kami memperolehinya daripada Jabatan Perangkaan melalui Penyiasatan Industri. Komponen terakhir permintaan akhir iaitu eksport, data diperoleh daripada Perangkaan Perdagangan Luar Negeri yang disusun mengikut Piawaian Klasifikasi Perdagangan Antarabangsa (SITC).

Komponen input primer yang penting iaitu nilai ditambah, diperoleh daripada UPENS melalui laporan ekonomi yang dibekalkan. Walaupun data ini dalam bentuk aggregat, namun ianya sangat berguna sebagai nilai rujukan dalam menganggar nilai ditambah bagi setiap industri. Komponen cukai komoditi domestik dan import pula, data dibekalkan oleh Jabatan Perangkaan menerusi Penyiasatan Industri. Seperti eksport, data import turut diperoleh melalui Perangkaan Perdagangan Luar Negeri mengikut klasifikasi SITC. Di samping itu, data output bagi setiap industri diperoleh daripada penerbitan yang sama seperti yang dinyatakan.

\section{DAPATAN KAJIAN}

Dengan menggunakan teknik RAS, jadual input-output negeri telah dianggar pada tahun asas 2000 dan meliputi 58 industri di Selangor. Walau bagaimanapun, bagi tujuan pelaporan, penyelidik telah mengaggregat industri-industri tersebut kepada 10 sektor utama. Jadual 2 melaporkan jadual input-output yang telah dianggarkan. Setiap baris (i) jadual input-output menunjukkan aliran penawaran atau pembekalan output oleh sesebuah industri kepada industri-industri lain untuk digunakan sebagai input oleh industri-industri berkaitan. Lajur $(j)$ jadual input-output pula mengambarkan aliran permintaan output oleh sesebuah industri daripada industri-industri lain yang akan digunakan sebagai input pengeluarannya. Oleh kerana jadual input-output dibina berasaskan konsep perakaunan, maka jumlah input mestilah bersamaan jumlah output. Keseluruhan output yang dijana di Selangor ialah sebanyak RM347,961 juta. Daripada jumlah ini sebanyak RM200,379 
juta ataupun 58\% dijana oleh sektor industri manakala selebihnya dijana oleh sektor bukan-industri seperti isirumah dan kerajaan. Sektor pembuatan didapati menjadi penyumbang utama kepada penjanaan output Selangor iaitu sebanyak RM 121,049 juta.

Selain daripada output, maklumat lain pada Jadual 2 yang boleh dijadikan perbincangan utama ialah sumbangan industri kepada penjanaan nilai ditambah dan sumbangan sektor perbelanjaan akhir ke atas ekonomi Selangor. Malah, kedua-dua komponen ini merupakan komponen utama dalam penggiraan KDNK negeri. Jadual 3 menunjukkan nilai ditambah kasar yang dijana oleh semua aktiviti di Selangor iaitu sebanyak RM75,185 juta. Sektor pembuatan dilihat menjadi penjana utama kepada nilai ditambah negeri yang menyumbang sebanyak RM39,681 juta. Industri peralatan elektronik, peralatan elektrik dan kenderaan bermotor di antara industri-industri di bawah sektor pembuatan yang menjadi penyumbang utama kepada sektor ini. Industri-industri ini walau bagaimanapun menjana nilai ditambah yang sederhana dalam industrinya sendiri kerana ia merupakan industri yang tidak berasaskan sumber. Sektor perdagangan, peruncitan, hotel dan restoran pula menjadi penyumbang kedua terbesar kepada nilai ditambah Selangor dan diikuti oleh sektor perbankan, hartanah dan perkhidmatan perniagaan, sektor perkhidmatan lain, dan sektor pembinaan.

Permintaan luar iaitu eksport menjadi penyumbang utama kepada perbelanjaan akhir ke atas barangan dan perkhidmatan di Selangor. Walaupun begitu, penggunaan import oleh sektor-sektor ekonomi di Selangor juga adalah tinggi. Pada tahun 2000, negeri Selangor mencatat eksport sebanyak RM89,765 juta manakala penggunaan import sebanyak RM73,094 juta. Keluaran elektronik dan elektrik merupakan komoditi eksport utama bagi Selangor yang menyumbang hampir $40 \%$ daripada keseluruhan eksport negeri. Walau bagaimanapun, industri ini turut mengimport bahan-bahan mentah daripada luar negara dalam kadar yang tinggi iaitu $28 \%$ daripada keseluruhan import negeri. Ini diikuti oleh industri pembinaan dan kenderaan bermotor. Penggunaan swasta adalah elemen yang kedua terbesar di antara perbelanjaan akhir ke atas barangan dan perkhidmatan yang menyumbang sebanyak RM33,818 juta. Perbelanjaan ini kebanyakkan terdiri daripada perbelanjaan isi rumah ke atas komoditi kenderaan bermotor, hotel dan restoran, dan hartanah berbanding dengan komoditi-komoditi lain seperti makanan. Ini menunjukkan bahawa pendapatan per kapita penduduk di negeri Selangor adalah tinggi yang diterjemahkan kepada peningkatan kuasa beli penduduk. Dalam tempoh yang sama, perbelanjaan kerajaan negeri ke atas barangan dan perkhidmatan direkodkan sebanyak RM1,006 juta. Di samping itu, RM1,508 juta adalah disumbangkan oleh perubahan stok dan RM19,258 juta daripada pengumpulan modal tetap kasar. 


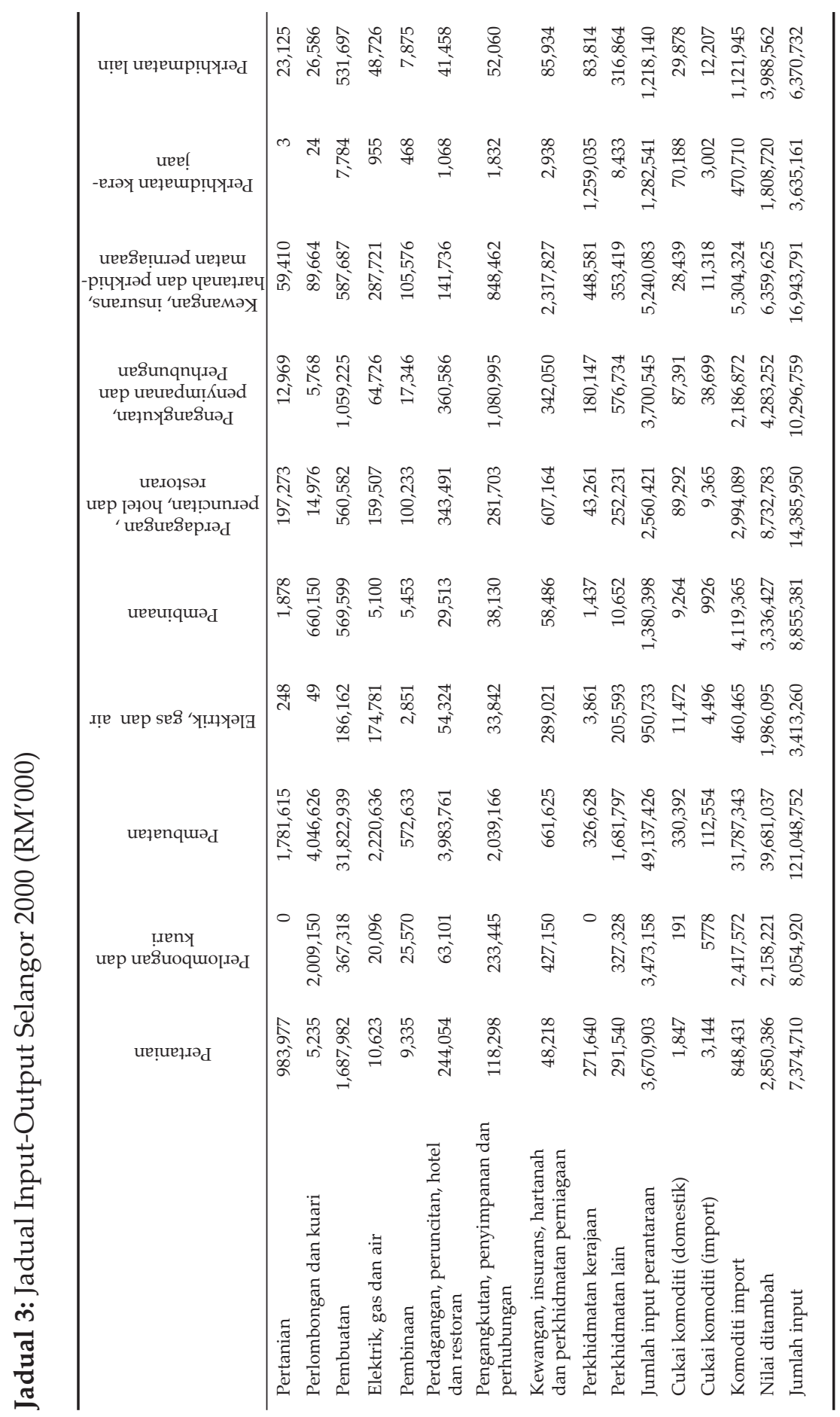

IJMS 16 (1), 1-30 (2009) 


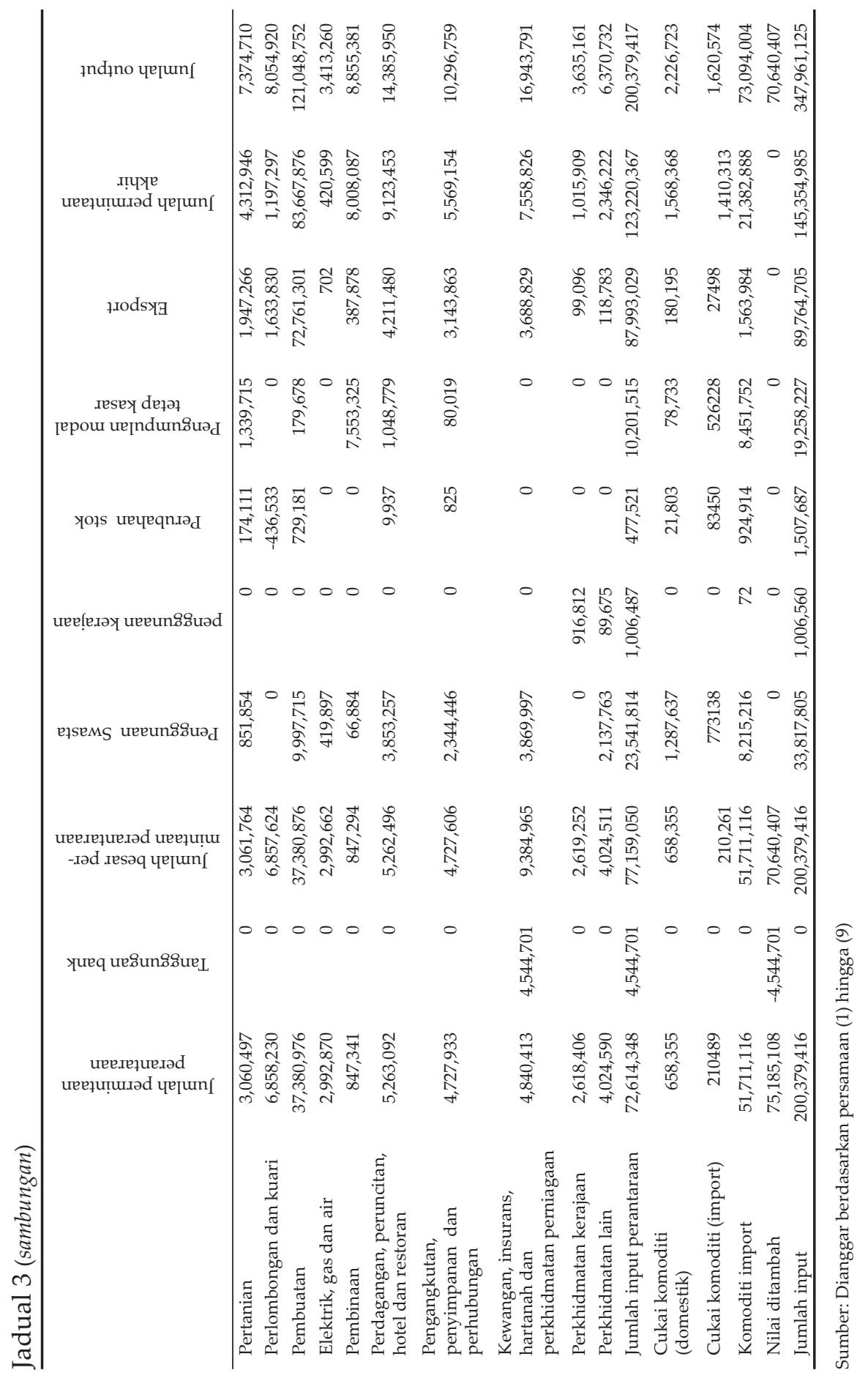

14 IJMS 16 (1), 1-30 (2009) 


\section{Struktur Pengeluaran Industri}

Dalam merencana pembangunan sektor perindustrian negeri, maklumat penting yang perlu diketahui ialah struktur pengeluaran setiap industriindustri. Untuk itu, jadual input-output menyediakan kerangka analisis yang komprehensif ke atas struktur pengeluaran industri yang diukur melalui struktur permintaan dan penawaran industri. Struktur permintaan terdiri daripada aliran penggunaan input oleh industri manakala struktur penawaran pula menunjukkan aliran pembekalan output kepada industri. Analisis ke atas struktur permintaan dan penawaran sektor-sektor utama di Selangor ditunjukkan pada Jadual 4. Analisis terperinci ke atas keseluruhan industri ada disertakan pada Lampiran 1 artikel ini. Ringkasan penerangan empirikal ke atas analisis struktur permintaan dan penawaran pula boleh dirujuk pada Lampiran 2.

Dalam pengeluaran, industri memerlukan dua jenis input, iaitu input perantaraan dan input primer. Input perantaraan adalah input-input yang diperoleh daripada industri-industri lain manakala input primer pula adalah input yang diminta dari sektor bukan-industri yang merangkumi import, cukai tak langsung dan faktor-faktor pengeluaran (diukur berdasarkan nilai ditambah). Jadual 4 menunjukkan variasi struktur input dalam setiap industri di Selangor. Secara purata, bagi setiap unit output yang dikeluarkan, industri di Selangor mengguna $31.60 \%$ input perantaraan, $44.63 \%$ unit faktor pengeluaran (nilai ditambah), $23.17 \%$ import dan $0.60 \%$ cukai tak langsung. Perangkaan ini menunjukkan bahawa faktor pengeluaran merupakan input utama yang digunakan dalam proses pengeluaran dan diikuti oleh penggunaan input daripada industri-industri lain serta penggunaan import.

Sektor pertanian, perlombongan dan kuari, dan pembuatan merupakan sektor-sektor yang memiliki kadar saling bergantungan input yang tinggi antara industri berbanding sektor-sektor lain. Sektor-sektor ini menggunakan hampir $45 \%$ output yang dikeluarkan oleh industriindustri lain sebagai inputnya. Analisis terperinci ke atas keseluruhan industri menunjukkan industri perternakan merupakan antara industri utama di bawah sektor pertanian yang menyerap input-input daripada industri lain dalam kadar yang tinggi. Bagi sektor pembuatan, industri minyak dan lemak didapati di antara industri yang banyak mengguna input-input daripada industri lain. Walau bagaimanapun, sektor perlombongan dan kuari, dan pembuatan turut menjana bocoran yang agak tinggi kepada ekonomi dalam bentuk import. Perlu ditegaskan di sini sektor pembinaan merupakan sektor yang mempunyai bocoran (import) yang paling tinggi iaitu $46.52 \%$ daripada keseluruhan inputnya. Disebabkan berlakunya bocoran yang tinggi dalam ekonomi, sektor pembinaan menyumbang hanya $37.68 \%$ kepada penjanaan nilai ditambah. 


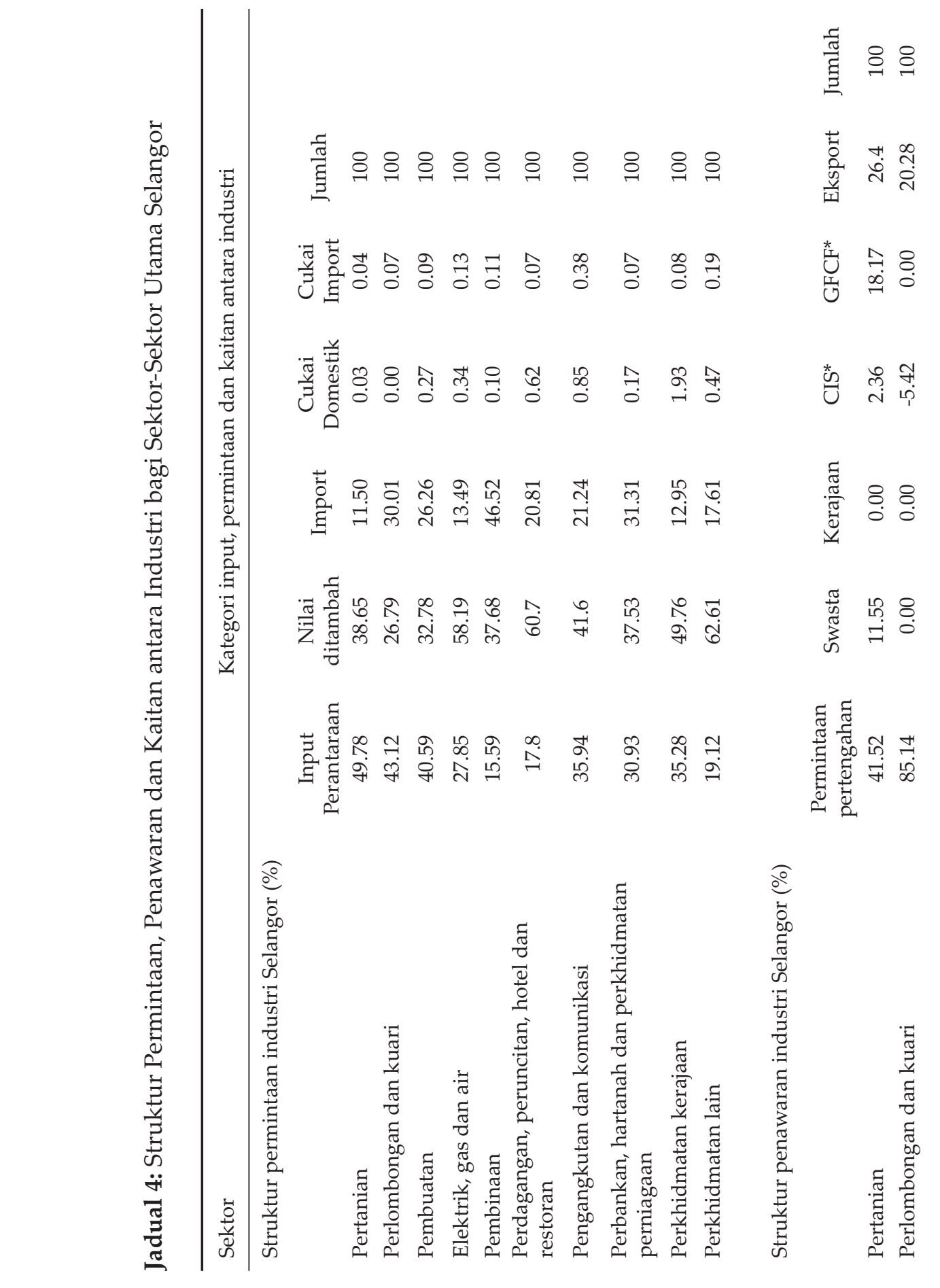

16 IJMS 16 (1), 1-30 (2009) 


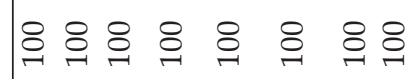

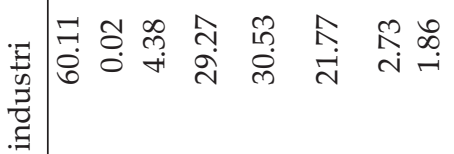

劳

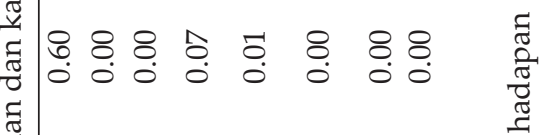

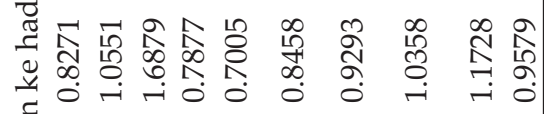

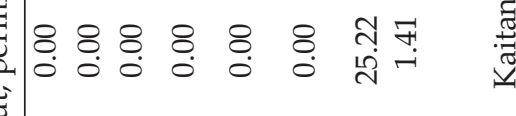

䒕

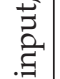

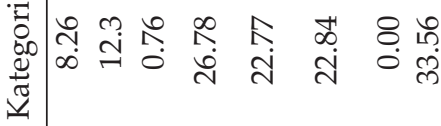

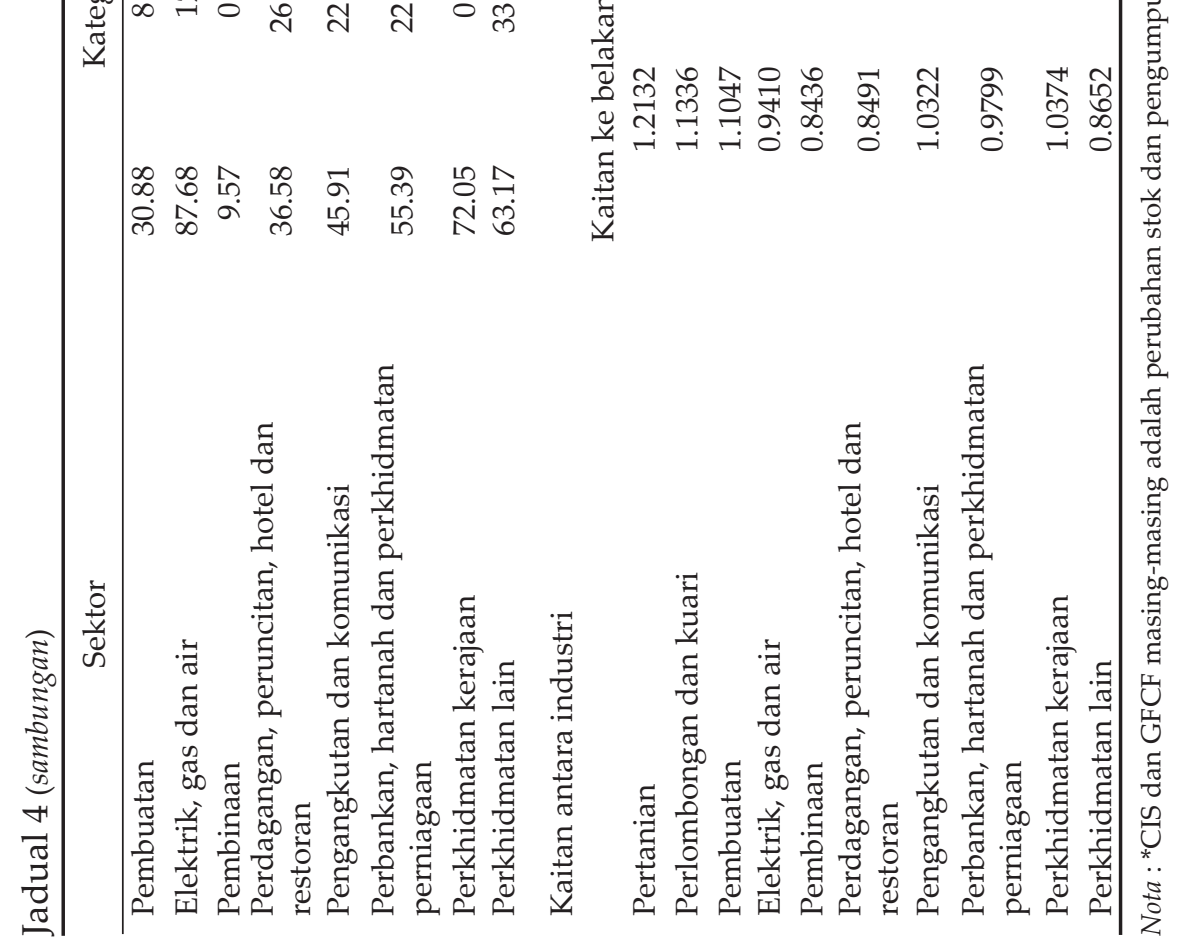

IJMS 16 (1), 1-30 (2009) 
Sebaliknya, walaupun sektor perkhidmatan lain dan perdagangan, peruncitan, hotel dan restoran memiliki struktur input yang agak lemah (kerana menyerap kuantiti input yang sederhana daripada industriindustri lain), sektor-sektor ini menyumbang lebih 60\% daripada perbelanjaan inputnya ke atas penjanaan nilai ditambah. Di samping itu, Jadual 4 juga menunjukkan bahawa kebanyakkan industri-industri di Selangor memiliki kadar saling bergantungan yang tinggi kepada import. Sektor perlombongan dan kuari, pembuatan dan pembinaan didapati bergantung kuat kepada import. Kajian mendapati sektor pembuatan mencatat penggunaan import yang tinggi terutamanya bagi industri-industri yang tidak berasaskan sumber seperti peralatan elektrik dan kenderaan bermotor. Akibat daripada pergantungan kepada import yang tinggi, kemampuan sektor-sektor ini untuk menjana pendapatan domestik (nilai ditambah) adalah lebih rendah berbanding dengan sektor-sektor lain. Tambahan lagi sektor-sektor ini turut terdedah kepada pengaruh pasaran perdagangan antarabangsa.

Struktur penawaran terdiri daripada dua komponen utama iaitu, permintaan perantaraan dan permintaan akhir. Spesifiknya, struktur penawaran menggambarkan bagaimana output daripada sesebuah industri itu diagihkan di dalam ekonomi. Keseluruhannya, Jadual 4 menunjukkan kebanyakkan output yang dikeluarkan oleh industri di Selangor adalah digunakan oleh industri-industri lain sebagai input perantaraan $(52.79 \%)$, diikuti oleh penggunaan swasta (13.88\%), eksport (19.74\%), penggumpulan modal tetap kasar (11.17), penggunaan kerajaan $(2.66 \%)$ dan perubahan stok $(-0.24 \%)$. Namun, hakikatnya setiap sektor mempunyai struktur penawaran yang berbeza antara satu dengan yang lain.

Perangkaan menunjukkan lebih 85\% daripada output yang dikeluarkan oleh sektor perlombongan dan kuari, dan elektrik, gas dan air digunakan olehindustri-industri di Selangor. Ini menunjukkan bahawa sektor-sektor tersebut mempunyai saling bergantungan output yang tinggi antara industri. Ringkasnya, sektor-sektor tersebut merupakan pembekal input utama kepada sektor-sektor lain. Walau bagaimanapun, sektor-sektor ini memiliki pasaran eksport yang lemah berbanding sektor-sektor lain seperti sektor pembuatan.

Sektor pembuatan dilihat lebih berorientasikan eksport dengan 60\% daripada output yang dijanakan akan digunakan untuk eksport, manakala selebihnya untuk permintaan domestik. Industri-industri seperti keluaran elektronik, perabot dan kelengkapan logam, 
dan pembuatan lain didapati antara penyumbang utama kepada eksport sektor pembuatan. Walaupun sektor pembuatan merupakan penyumbang utama kepada ekonomi negeri, sektor ini didapati terlalu bergantung kepada permintaan eksport. Ini membawa implikasi bahawa industri ini memiliki struktur permintaan yang lemah. Jika berlaku ketidaktentuan perdagangan dunia, permintaan output industri ini juga akan terjejas terutama kumpulan industri-industri yang tidak berasaskan sumber seperti elektrik dan elektronik.

\section{Kaitan Antara Industri}

Setiap industri di dalam ekonomi saling berinteraksi dan berkait antara satu sama lain di dalam pengeluaran dan penggunaan output. Saling bergantungan antara pengeluaran dan penggunaan output oleh industriindustri dapat diterjemah daripada pekali matrik songsang Leontief yang mengambil kira pertalian langsung dan tak langsung. Kaitan ini selalunya dirujuk sebagai kaitan ke belakang dan ke hadapan. Kaitan ke belakang ialah kaitan kepelbagaian input yang diguna oleh sesebuah industri (katakan industri j) daripada output yang dikeluarkan oleh industri-industri lain (katakan industri i) untuk mengeluarkan sejumlah output industri $j$. Oleh kerana kaitan ke belakang melibatkan pembelian input daripada pelbagai industri, maka ahli ekonomi mengaitkannya dengan kaitan penggunaan dalam industri. Berbeza dengan kaitan ke belakang, kaitan ke hadapan menunjukkan pertalian penawaran output. Kaitan ini menggambarkan pertalian penjualan output oleh industri $i$ kepada industri $j$ untuk digunakan di dalam proses pengeluaran output industri $j$. Ringkasnya, kaitan ke hadapan merupakan kaitan pembekalan antara industri dalam ekonomi.

Tujuan utama analisis kaitan ke belakang dan hadapan dijalankan bertujuan mengenal pasti sektor strategik dalam sesebuah ekonomi. Jika sektor strategik dikenal pasti maka mudah bagi penggubal dasar untuk merangka dasar terhadap pertumbuhan ekonomi dengan memberi suntikan kepada sektor-sektor tersebut. Untuk mengenal pasti sektor strategik dalam sesebuah ekonomi, sesebuah sektor itu perlu memiliki kaitan kuat bagi kedua-dua kaitan tadi. Kaitan kuat di sini ditakrifkan sebagai indeks kaitan ke belakang ataupun hadapan yang nilainya melebihi purata keseluruhan industri, iaitu melebihi daripada nilai 1. Penerangan empirikal ke atas penjanaan indeks kaitan ke belakang dan hadapan boleh dirujuk pada Lampiran 2 artikel ini.

Jadual 4 melaporkan indeks kaitan belakang dan hadapan yang dikira bagi setiap sektor di Selangor (sila rujuk Lampiran 1 bagi memperoleh 
keseluruhan indeks kaitan antara industri). Sektor pertanian, perlombongan dan kuari, pembuatan, pengangkutan, penyimpanan dan perhubungan, dan perkhidmatan kerajaan dilihat memiliki indeks kaitan ke belakang yang tinggi (melebihi 1 ) berbanding dengan sektorsektor lain. Ini membawa implikasi bahawa sektor-sektor ini memiliki rantaian penggunaan input antara industri yang kuat berbanding sektorsektor lain di dalam ekonomi Selangor. Peningkatan permintaan akhir sektor-sektor ini bukan sahaja akan menjana output tambahan untuk sektornya malahan sektor-sektor lain juga di dalam ekonomi. Kajian juga mendapati indeks kaitan ke belakang kebanyakkannya didorong oleh rantaian penggunaan industri-industri dibawah sektor pembuatan seperti industri minyak dan lemak, keluaran roti, coklat dan konfeksi gula, dan mineral bukan logam.

Sektor perlombongan dan kuari, pembuatan, kewangan, insuran, hartanah dan perkhidmatan perniagaan, dan perkhidmatan kerajaan mempunyai indeks kaitan ke hadapan yang tinggi berbanding dengan sektor-sektor lain. Justeru itu, sektor-sektor ini memiliki rantaian pembekalan output antara industri yang kuat. Tidak seperti kaitan ke belakang, kaitan ke hadapan kebanyakannya disokong oleh pengaruh rantaian pembekalan industri-industri di bawah sektor perkhidmatan. Ini termasuklah industri perkhidmatan kerajaan, pendidikan swasta, hartanah dan hak milik rumah, pengangkutan, perdagangan borong dan runcit, dan elektrik dan gas.

Analisis ke atas kaitan antara industri merumuskan sektor pembuatan, perlombongan dan kuari, dan perkhidmatan kerajaan merupakan sektor-sektor strategik yang mempunyai potensi tinggi di dalam menjana ekonomi Selangor. Hal ini kerana indeks kaitan ke hadapan dan belakang sektor-sektor ini adalah tinggi iaitu melebihi daripada purata keseluruhan ekonomi. Dalam memastikan ekonomi negeri bertumbuh dengan kadar pertumbuhan yang tinggi, sektor-sektor ini perlu diutamakan kerana ia memiliki rantaian penggunaan dan pembekalan output yang tinggi dalam ekonomi. Sebarang peningkatan permintaan akhir sektor ini, contohnya pertambahan pelaburan, akan menjana output keseluruhan sektor di dalam ekonomi.

\section{RUMUSAN}

Artikel ini membentangkan hasil kajian ke atas pembangunan jadual input-ouput Selangor pada tahun asas 2000 dengan menggunakan 
pendekatan separa-tinjauan, iaitu aplikasi teknik RAS. Teknik RAS hanya menganggar Sukuan I jadual input-output, iaitu aliran permintaan dan penawaran antara industri manakala aliran-aliran lain disusun berdasarkan data sebenar yang diperolehi daripada pelbagai sumber. Teknik ini mengandaikan struktur penggunaan input dan teknologi pengeluaran Selangor adalah bersamaan dengan struktur pengeluaran nasional. Jadual input-output yang dianggar kemudiannya digunakan untuk menjalankan analisis ke atas struktur pengeluaran industri di Selangor. Malahan analisis ke atas struktur pengeluaran industri menjadi maklumat awal kepada penggubal dasar dalam menentu arah tuju pembangunan ekonomi negeri melalui pembangunan sektor perindustrian.

Dapatan kajian dapat dirumuskan seperti berikut. Kajian ke atas setiap industri mendapati sektor pembuatan merupakan penyumbang utama kepada output dan nilai ditambah negeri. Industri-industri besar seperti keluaran elektronik, jentera elektrik dan kenderaan bermotor di antara penyumbang utama kepada pertumbuhan sektor pembuatan. Industri-industri ini walau bagaimanapun menjana nilai ditambah yang sederhana dalam industrinya sendiri kerana ia merupakan industri yang tidak berasaskan sumber. Di samping itu, kajian turut mendapati Selangor memiliki struktur pengeluaran industri yang sederhana dan terlalu bergantung kepada import dan eksport. Didapati, walaupun sebahagian daripada industri mengguna input-input domestik dalam kadar yang tinggi, industri-industri tersebut hanya menjana nilai ditambah dalam kadar yang sederhana akibat kebergantungan yang tinggi ke atas import. Begitu juga, walaupun industri-industri seperti perkhidmatan lain dan perdagangan, peruncitan, hotel dan restoran mampu menyumbang nilai ditambah yang tinggi, industri-industri tersebut memiliki kebergantungan yang lemah antara industri. Analisis kaitan antara industri mendapati sektor pembuatan, perlombongan dan kuari, dan perkhidmatan kerajaan merupakan sektor-sektor strategik di Selangor yang berpotensi memberi impak besar kepada pertumbuhan ekonomi Selangor. Sebarang suntikan pelaburan ke atas industriindustri ini akan menarik industri-industri lain untuk berkembang.

\section{PENGHARGAAN}

Penulis merakamkan penghargaan kepada Unit Perancang Ekonomi Negeri Selangor (UPENS) di atas bantuan dana dan kerjasama yang telah diberikan di dalam menjayakan projek penyelidikan ini. 


\section{RUJUKAN}

Czamanski, S., \& Malizia, E.E. (1969). Applicability and limitations in the use of national input-output tables for regional studies. Papers in Regional Science Association, 23, 65-77.

Dewhurst, J.H.L. (1992). Using the RAS technique as a test of hybrid method of regional input-output table updating. Regional Studies, 26(1), 81-91.

Harrigan, F., McGilvray, J., \& McNicoll, I. (1980). A comparison of regional and national technical structures. The Economic Journal, 90(360), 795-810.

Jabatan Perangkaan. Tinjauan perbelanjaan isirumah 1998/99 (tidak diterbitkan). Kuala Lumpur: Percetakan Nasional Malaysia Berhad.

Jabatan Perangkaan. Penyiasatan industripembuatan 2000 (tidakditerbitkan). Kuala Lumpur: Percetakan Nasional Malaysia Berhad.

Jabatan Perangkaan (2000). Piawaian klasifikasi industri Malaysia 2000. Kuala Lumpur: Percetakan Nasional Malaysia Berhad.

Jabatan Perangkaan (2002). Banci industri pembuatan 2000. Kuala Lumpur: Percetakan Nasional Malaysia Berhad.

Jabatan Perangkaan (2004). Akaun keluaran dan perbelanjaan negara tahunan 1987-2003. Kuala Lumpur: Percetakan Nasional Malaysia Berhad.

Jabatan Perangkaan (2006). Jadual input-output 2000. Kuala Lumpur: Percetakan Nasional Malaysia Berhad

Morrison, W.I., \& Smith, P. (1974). Nonsurvey input-output techniques at the small area level: An evaluation. Journal of Regional Science, 14(1), 1-14.

Saari, M.Y., \& Zakariah, A.R. (2006). Analisis dan aplikasi input-output. Kuala Lumpur: Dewan Bahasa dan Pustaka.

Sawyer, C., \& Miller, R.E. (1983). Experiments in regionalization of a regional input-output table. Environment and Planning A, 15(11), 1501-1520.

Simpson, D., \& Tsukui, J. (1965). The fundamental structure of inputoutput tables and international comparison. The Review of Economics and Statistics, 47(4), 434-446.

Stone, R. (1963). A computable model of economic growth. In: Chapman and Hall,

Unit Perancang Ekonomi Negeri Selangor (2000). Laporan ekonomi negeri Selangor Darul Ehsan 2000. Kuala Lumpur: Percetakan CETAKRAPI.

Unit Perancang Ekonomi Negeri Selangor (2004). Selangor negeri maju 2005: Kajian daya saing negeri Selangor. Shah Alam: Unit Perancang Ekonomi Negeri Selangor. 
Unit Perancang Ekonomi (2001). Rancangan Malaysia Kelapan, 2000-2005. Kuala Lumpur: Percetakan Nasional Malaysia Berhad.

Unit Perancang Ekonomi (2006). Rancangan Malaysia Kesembilan, 20062010. Kuala Lumpur: Percetakan Nasional Malaysia Berhad. 


\section{Lampiran 1: Struktur Permintaan Keseluruhan Industri Selangor (\%)}

\begin{tabular}{|c|c|c|c|c|c|c|}
\hline \multirow{2}{*}{\multicolumn{2}{|c|}{ Industri }} & \multirow{2}{*}{$\begin{array}{c}\text { Input } \\
\text { Perantaraan }\end{array}$} & \multirow{2}{*}{ Import } & \multicolumn{2}{|c|}{ Cukai } & \multirow{2}{*}{$\begin{array}{c}\text { Nilai } \\
\text { ditambah }\end{array}$} \\
\hline & & & & Domestik & Import & \\
\hline 1 & Produk pertanian dan lain-lain & 23.21 & 9.12 & 0.04 & 0.11 & 67.52 \\
\hline 2 & Produk utama getah & 25.49 & 31.73 & 0.10 & 0.07 & 42.62 \\
\hline 3 & Produk utama kelapa sawit & 22.75 & 18.83 & 0.02 & 0.04 & 58.36 \\
\hline 4 & Penternakan & 78.70 & 11.75 & 0.01 & 0.03 & 9.51 \\
\hline 5 & Perhutanan dan pembalakan & 73.25 & 4.22 & 0.00 & 0.01 & 22.52 \\
\hline 6 & Perikanan & 38.57 & 9.76 & 0.02 & 0.02 & 51.63 \\
\hline 7 & Perlombongan dan kauri & 43.12 & 30.01 & 0.00 & 0.07 & 26.79 \\
\hline 8 & Daging, dan produk daging & 47.77 & 25.57 & 0.15 & 0.09 & 26.43 \\
\hline 9 & Perusahaan makanan & 55.39 & 23.81 & 0.05 & 0.08 & 20.66 \\
\hline 10 & Minyak dan lemak & 81.97 & 0.59 & 0.05 & 0.00 & 17.38 \\
\hline 11 & Produk bijirin & 28.07 & 39.58 & 0.14 & 0.14 & 32.06 \\
\hline 12 & $\begin{array}{l}\text { Produk roti, coklat dan konfeksi } \\
\text { gula }\end{array}$ & 67.85 & 2.58 & 0.22 & 0.01 & 29.33 \\
\hline 13 & Makanan lain & 30.18 & 37.98 & 0.09 & 0.14 & 31.61 \\
\hline 14 & Makanan haiwan & 56.52 & 23.96 & 0.02 & 0.09 & 19.41 \\
\hline 15 & Minuman & 39.33 & 16.22 & 8.24 & 0.06 & 36.15 \\
\hline 16 & Tembakau & 26.67 & 38.60 & 3.32 & 0.14 & 31.27 \\
\hline 17 & Produk tekstil & 23.60 & 19.47 & 0.10 & 0.07 & 56.76 \\
\hline 18 & Lain-lain produk tekstil & 39.34 & 10.37 & 0.16 & 0.03 & 50.10 \\
\hline 19 & Produk kayu & 55.14 & 3.54 & 0.08 & 0.01 & 41.23 \\
\hline 20 & Perabot dan kelengkapan logam & 58.43 & 9.12 & 0.16 & 0.03 & 32.27 \\
\hline 21 & Produk kertas dan percetakan & 41.82 & 16.45 & 0.16 & 0.05 & 41.52 \\
\hline 22 & Industri bahan kimia & 32.39 & 37.18 & 0.19 & 0.13 & 30.11 \\
\hline 23 & Cat dan lakuer & 56.69 & 14.71 & 0.47 & 0.05 & 28.09 \\
\hline 24 & Lain-lain produk bahan kimia & 26.00 & 15.82 & 0.16 & 0.05 & 57.97 \\
\hline 25 & Petroleum dan arang batu & 63.70 & 0.00 & 0.00 & 0.00 & 36.30 \\
\hline 26 & Getah diproses & 59.86 & 22.08 & 0.10 & 0.08 & 17.88 \\
\hline 27 & Produk getah & 47.95 & 10.51 & 0.50 & 0.03 & 41.01 \\
\hline 28 & Produk plastik & 64.08 & 0.00 & 0.00 & 0.00 & 35.92 \\
\hline 29 & Industri gelas dan kaca & 31.29 & 15.07 & 0.11 & 0.05 & 53.48 \\
\hline 30 & Simen, kapur dan plaster & 53.59 & 1.81 & 0.17 & 0.01 & 44.43 \\
\hline 31 & Bahan mineral bukan logam & 66.18 & 3.70 & 0.27 & 0.01 & 29.84 \\
\hline 32 & Industri struktur logam & 54.54 & 18.02 & 0.05 & 0.06 & 27.33 \\
\hline 33 & Produk industri logam lain & 29.58 & 27.22 & 0.07 & 0.09 & 43.04 \\
\hline 34 & Peralatan berasaskan elektronik & 43.95 & 26.33 & 0.11 & 0.09 & 29.52 \\
\hline 35 & Peralatan berasaskan elektrik & 26.85 & 38.76 & 0.08 & 0.14 & 34.17 \\
\hline 36 & Kenderaan bermotor & 44.92 & 30.05 & 0.59 & 0.11 & 24.34 \\
\hline 37 & $\begin{array}{l}\text { Kelengkapan pengangkutan } \\
\text { yang lain }\end{array}$ & 45.92 & 17.22 & 0.29 & 0.06 & 36.51 \\
\hline 38 & Produk pembuatan yang lain & 29.72 & 36.47 & 0.03 & 0.13 & 33.66 \\
\hline 39 & Elektrik dan gas & 30.57 & 8.70 & 0.38 & 0.15 & 60.20 \\
\hline 40 & Air & 6.08 & 51.89 & 0.01 & 0.00 & 42.02 \\
\hline 41 & Bangunan dan pembinaan & 15.59 & 46.52 & 0.10 & 0.11 & 37.68 \\
\hline 42 & Perdagangan borong dan runcit & 20.37 & 9.64 & 0.80 & 0.03 & 69.16 \\
\hline 43 & Hotel dan restoran & 11.35 & 48.80 & 0.17 & 0.16 & 39.52 \\
\hline 44 & Pengangkutan & 41.84 & 24.17 & 0.53 & 0.45 & 33.01 \\
\hline 45 & Komunikasi & 24.48 & 15.55 & 1.47 & 0.23 & 58.26 \\
\hline 46 & Perkhidmatan bank & 38.23 & 20.71 & 0.12 & 0.04 & 40.88 \\
\hline 47 & Insurans & 37.92 & 27.25 & 0.04 & 0.06 & 34.74 \\
\hline
\end{tabular}


Lampiran 1 (sambungan)

\begin{tabular}{llccccc}
\hline & \multicolumn{1}{c}{ Industri } & Input & \multirow{2}{*}{ Import } & \multicolumn{2}{c}{ Cukai } & Nilai \\
& Perantaraan & & & Domestik & Import & ditambah \\
\hline 48 & Hartanah dan hak milik rumah & 45.03 & 12.35 & 0.37 & 0.03 & 42.23 \\
49 & Perkhidmatan perniagaan & 6.86 & 63.33 & 0.05 & 0.14 & 29.62 \\
50 & Pendidikan swasta & 19.09 & 8.13 & 0.38 & 0.09 & 72.32 \\
51 & Kesihatan swasta & 23.11 & 27.27 & 0.58 & 0.08 & 48.97 \\
52 & Rekreasi dan kebudayaan & 9.47 & 13.54 & 0.54 & 0.03 & 76.43 \\
53 & Penyelenggaraan motor & 31.87 & 33.09 & 0.47 & 2.56 & 32.00 \\
54 & Penyelenggaraan lain dan & 17.56 & 42.94 & 0.17 & 0.10 & 39.23 \\
& pembersihan & & & & & \\
55 & Pentadbiran awam dan & 35.91 & 13.06 & 1.91 & 0.09 & 49.03 \\
& pertahanan & & & & & \\
56 & Pentadbiran awam lain & 33.32 & 12.61 & 2.00 & 0.07 & 52.00 \\
57 & Institusi bukan untung swasta & 34.88 & 13.83 & 1.10 & 0.10 & 50.09 \\
58 & Perkhidmatan swasta lain & 11.31 & 37.91 & 0.26 & 0.08 & 50.44 \\
\hline
\end{tabular}

Struktur Penawaran Keseluruhan Industri Selangor (\%)

\begin{tabular}{|c|c|c|c|c|c|c|c|}
\hline & Industri & $\begin{array}{l}\text { Permintaan } \\
\text { perantaraan }\end{array}$ & $\begin{array}{c}\text { Penggunaan } \\
\text { swasta }\end{array}$ & $\begin{array}{c}\text { Penggunaan } \\
\text { kerajaan }\end{array}$ & CIS* & GFCF* $^{*}$ & Eksport \\
\hline 1 & $\begin{array}{l}\text { Produk pertanian } \\
\text { dan lain-lain }\end{array}$ & 50.50 & 28.27 & 0.00 & -0.60 & 0.87 & 20.96 \\
\hline 2 & Produk utama getah & 23.64 & 0.00 & 0.00 & 47.15 & 4.41 & 24.80 \\
\hline 3 & $\begin{array}{l}\text { Produk utama } \\
\text { kelapa sawit }\end{array}$ & 58.03 & 0.00 & 0.00 & -112.33 & 154.30 & 0.00 \\
\hline 4 & Penternakan & 51.45 & 25.14 & 0.00 & 1.51 & 15.25 & 6.65 \\
\hline 5 & $\begin{array}{l}\text { Perhutanan dan } \\
\text { pembalakan }\end{array}$ & 9.94 & 0.00 & 0.00 & 27.51 & 0.00 & 62.56 \\
\hline 6 & Perikanan & 85.15 & 14.08 & 0.00 & 0.02 & 0.00 & 0.74 \\
\hline 7 & $\begin{array}{l}\text { Perlombongan dan } \\
\text { kuari }\end{array}$ & 85.14 & 0.00 & 0.00 & -5.42 & 0.00 & 20.28 \\
\hline 8 & $\begin{array}{l}\text { Daging, dan produk } \\
\text { daging }\end{array}$ & 60.69 & 29.33 & 0.00 & -1.02 & 0.06 & 10.94 \\
\hline 9 & $\begin{array}{l}\text { Perusahaan } \\
\text { makanan }\end{array}$ & 35.45 & 6.05 & 0.00 & -11.69 & 0.24 & 69.95 \\
\hline 10 & Minyak dan lemak & 76.77 & 4.17 & 0.00 & -0.51 & 0.19 & 19.38 \\
\hline 11 & Produk bijirin & 40.85 & 43.10 & 0.00 & 0.58 & 0.23 & 15.24 \\
\hline 12 & $\begin{array}{l}\text { Produk roti, coklat } \\
\text { dan konfeksi gula }\end{array}$ & 20.53 & 29.34 & 0.00 & -1.03 & 0.11 & 51.05 \\
\hline 13 & Makanan lain & 29.94 & 42.15 & 0.00 & 1.92 & 0.16 & 25.83 \\
\hline 14 & Makanan haiwan & 86.51 & 12.10 & 0.00 & 0.15 & 0.26 & 0.99 \\
\hline 15 & Minuman & 44.16 & 43.70 & 0.00 & 0.34 & 0.09 & 11.71 \\
\hline 16 & Tembakau & 17.54 & 30.96 & 0.00 & -1.18 & 0.09 & 52.59 \\
\hline 17 & Produk tekstil & 29.32 & 32.01 & 0.00 & -1.70 & 0.91 & 39.46 \\
\hline 18 & $\begin{array}{l}\text { Lain-lain produk } \\
\text { tekstil }\end{array}$ & 20.00 & 21.91 & 0.00 & -2.35 & 0.41 & 60.04 \\
\hline 19 & Produk kayu & 23.51 & 1.89 & 0.00 & 1.37 & 0.78 & 72.45 \\
\hline 20 & $\begin{array}{l}\text { Perabot dan keleng- } \\
\text { kapan logam }\end{array}$ & 13.53 & 0.27 & 0.00 & 0.34 & 0.09 & 85.78 \\
\hline 21 & $\begin{array}{l}\text { Produk kertas dan } \\
\text { percetakan }\end{array}$ & 63.84 & 13.07 & 0.00 & 1.77 & 0.25 & 21.08 \\
\hline 22 & $\begin{array}{l}\text { Industri bahan } \\
\text { kimia }\end{array}$ & 22.07 & 0.74 & 0.00 & -7.17 & 0.67 & 83.70 \\
\hline 23 & Cat dan lakuer & 42.29 & 7.40 & 0.00 & 0.05 & 0.04 & 50.22 \\
\hline 24 & $\begin{array}{l}\text { Lain-lain produk } \\
\text { bahan kimia }\end{array}$ & 31.60 & 8.46 & 0.00 & 1.19 & 0.21 & 58.54 \\
\hline
\end{tabular}


Lampiran 1 (sambungan)

\begin{tabular}{|c|c|c|c|c|c|c|c|}
\hline & Industri & $\begin{array}{l}\text { Permintaan } \\
\text { perantaraan }\end{array}$ & $\begin{array}{l}\text { Penggunaan } \\
\text { swasta }\end{array}$ & $\begin{array}{l}\text { Penggunaan } \\
\text { kerajaan }\end{array}$ & $\mathrm{CIS}^{*}$ & $\mathrm{GFCF}^{*}$ & Eksport \\
\hline 25 & $\begin{array}{l}\text { Petroleum dan } \\
\text { arang batu }\end{array}$ & 38.24 & 29.88 & 0.00 & -2.23 & 2.93 & 31.19 \\
\hline 26 & Getah diproses & 43.04 & 0.00 & 0.00 & 0.22 & 0.58 & 56.16 \\
\hline 27 & Produk getah & 20.15 & 6.29 & 0.00 & 1.07 & 0.16 & 72.33 \\
\hline 28 & Produk plastik & 2.65 & 25.62 & 0.00 & 1.99 & 0.13 & 69.60 \\
\hline 29 & $\begin{array}{l}\text { Industri gelas dan } \\
\text { kaca }\end{array}$ & 45.90 & 1.08 & 0.00 & 4.31 & 0.25 & 48.46 \\
\hline 30 & $\begin{array}{l}\text { Simen, kapur dan } \\
\text { plaster }\end{array}$ & 33.64 & 0.06 & 0.00 & 9.28 & 2.36 & 54.66 \\
\hline 31 & $\begin{array}{l}\text { Bahan mineral } \\
\text { bukan logam }\end{array}$ & 54.11 & 0.00 & 0.00 & 0.87 & 0.15 & 44.86 \\
\hline 32 & $\begin{array}{l}\text { Industri struktur } \\
\text { logam }\end{array}$ & 24.55 & 1.61 & 0.00 & 1.61 & 0.17 & 72.06 \\
\hline 33 & $\begin{array}{l}\text { Produk industri } \\
\text { logam lain }\end{array}$ & 34.09 & 1.21 & 0.00 & 11.28 & 0.11 & 53.31 \\
\hline 34 & $\begin{array}{l}\text { Peralatan } \\
\text { berasaskan } \\
\text { elektronik }\end{array}$ & 7.50 & 1.00 & 0.00 & -0.08 & 0.05 & 91.53 \\
\hline 35 & $\begin{array}{l}\text { Peralatan } \\
\text { berasaskan elektrik }\end{array}$ & 25.86 & 0.62 & 0.00 & 0.21 & 0.09 & 73.22 \\
\hline 36 & $\begin{array}{l}\text { Kenderaan } \\
\text { bermotor }\end{array}$ & 57.58 & 30.77 & 0.00 & 0.79 & 0.04 & 10.83 \\
\hline 37 & $\begin{array}{l}\text { Kelengkapan } \\
\text { pengangkutan yang } \\
\text { lain }\end{array}$ & 41.67 & 9.68 & 0.00 & 1.33 & 0.24 & 47.08 \\
\hline 38 & $\begin{array}{l}\text { Produk pembuatan } \\
\text { yang lain }\end{array}$ & 12.59 & 2.15 & 0.00 & 0.31 & 0.07 & 84.88 \\
\hline 39 & Elektrik dan gas & 87.67 & 12.32 & 0.00 & 0.00 & 0.00 & 0.01 \\
\hline 40 & Air & 87.77 & 12.15 & 0.00 & 0.00 & 0.00 & 0.09 \\
\hline 41 & $\begin{array}{l}\text { Bangunan dan } \\
\text { pembinaan }\end{array}$ & 9.57 & 0.76 & 0.00 & 0.00 & 85.30 & 4.38 \\
\hline 42 & $\begin{array}{l}\text { Perdagangan } \\
\text { borong dan runcit }\end{array}$ & 40.43 & 8.30 & 0.00 & 0.10 & 10.20 & 40.97 \\
\hline 43 & Hotel dan restoran & 26.94 & 73.06 & 0.00 & 0.00 & 0.00 & 0.00 \\
\hline 44 & Pengangkutan & 49.93 & 7.94 & 0.00 & 0.01 & 1.18 & 40.93 \\
\hline 45 & Komunikasi & 38.11 & 51.54 & 0.00 & 0.00 & 0.00 & 10.35 \\
\hline 46 & Perkhidmatan bank & 86.80 & 11.04 & 0.00 & 0.00 & 0.00 & 2.16 \\
\hline 47 & Insurans & 68.34 & 23.82 & 0.00 & 0.00 & 0.00 & 7.84 \\
\hline 48 & $\begin{array}{l}\text { Hartanah dan hak } \\
\text { milik rumah }\end{array}$ & 44.11 & 55.89 & 0.00 & 0.00 & 0.00 & 0.00 \\
\hline 49 & $\begin{array}{l}\text { Perkhidmatan } \\
\text { perniagaan }\end{array}$ & 25.86 & 4.55 & 0.00 & 0.00 & 0.00 & 69.59 \\
\hline 50 & Pendidikan swasta & 84.98 & 13.66 & 0.14 & 0.00 & 0.00 & 1.22 \\
\hline 51 & Kesihatan swasta & 25.76 & 67.50 & 1.18 & 0.00 & 0.00 & 5.55 \\
\hline 52 & $\begin{array}{l}\text { Rekreasi dan } \\
\text { kebudayaan }\end{array}$ & 76.49 & 23.15 & 0.00 & 0.00 & 0.00 & 0.37 \\
\hline 53 & $\begin{array}{l}\text { Penyelenggaraan } \\
\text { motor }\end{array}$ & 19.93 & 80.07 & 0.00 & 0.00 & 0.00 & 0.00 \\
\hline 54 & $\begin{array}{l}\text { Penyelenggaraan } \\
\text { lain dan } \\
\text { pembersihan }\end{array}$ & 86.98 & 13.02 & 0.00 & 0.00 & 0.00 & 0.00 \\
\hline 55 & $\begin{array}{l}\text { Pentadbiran awam } \\
\text { dan pertahanan }\end{array}$ & 67.47 & 0.00 & 32.53 & 0.00 & 0.00 & 0.00 \\
\hline 56 & $\begin{array}{l}\text { Pentadbiran awam } \\
\text { lain }\end{array}$ & 86.25 & 0.00 & 2.56 & 0.00 & 0.00 & 11.18 \\
\hline 57 & $\begin{array}{l}\text { Institusi bukan } \\
\text { untung swasta }\end{array}$ & 28.00 & 43.01 & 28.99 & 0.00 & 0.00 & 0.00 \\
\hline 58 & $\begin{array}{l}\text { Perkhidmatan } \\
\text { swasta lain }\end{array}$ & 51.59 & 48.04 & 0.00 & 0.00 & 0.00 & 0.37 \\
\hline
\end{tabular}

Nota : *CIS dan GFCF masing-masing adalah perubahan stok dan pengumpulan modal tetap kasar

26 IJMS 16 (1), 1-30 (2009) 
Lampiran 1 (sambungan)

Indeks Kaitan antara Industri bagi Keseluruhan Industri Selangor

\begin{tabular}{|c|c|c|c|c|c|}
\hline \multicolumn{2}{|r|}{ Industri } & \multicolumn{2}{|c|}{ Kaitan ke belakang } & \multicolumn{2}{|c|}{ Kaitan ke hadapan } \\
\hline & & Indeks & Kedudukan & Indeks & Kedudukan \\
\hline 1 & Produk pertanian dan lain-lain & 0.8022 & 49 & 1.2916 & 10 \\
\hline 2 & Produk utama getah & 0.8411 & 42 & 0.9288 & 20 \\
\hline 3 & Produk utama kelapa sawit & 0.8219 & 46 & 0.8240 & 28 \\
\hline 4 & Penternakan & 1.6087 & 2 & 1.0852 & 15 \\
\hline 5 & Perhutanan dan pembalakan & 1.3045 & 4 & 0.7012 & 46 \\
\hline 6 & Perikanan & 0.9823 & 27 & 1.7314 & 5 \\
\hline 7 & Perlombongan dan kuari & 1.0116 & 23 & 3.2239 & 1 \\
\hline 8 & Daging, dan produk daging & 1.1906 & 10 & 1.4925 & 6 \\
\hline 9 & Perusahaan makanan & 1.1592 & 13 & 0.6831 & 49 \\
\hline 10 & Minyak dan lemak & 2.1697 & 1 & 2.4190 & 2 \\
\hline 11 & Produk bijirin & 0.8427 & 41 & 0.7268 & 43 \\
\hline 12 & $\begin{array}{l}\text { Produk roti, coklat dan konfeksi } \\
\text { gula }\end{array}$ & 1.3587 & 3 & 0.7412 & 41 \\
\hline 13 & Makanan lain & 0.9126 & 35 & 0.8865 & 22 \\
\hline 14 & Makanan haiwan & 1.2754 & 6 & 1.2170 & 13 \\
\hline 15 & Minuman & 1.0095 & 24 & 0.9251 & 21 \\
\hline 16 & Tembakau & 0.8253 & 44 & 0.7340 & 42 \\
\hline 17 & Produk tekstil & 0.8246 & 45 & 0.7503 & 39 \\
\hline 18 & Lain-lain produk tekstil & 0.9737 & 28 & 0.6378 & 54 \\
\hline 19 & Produk kayu & 1.1632 & 12 & 0.6641 & 50 \\
\hline 20 & Perabot dan kelengkapan logam & 1.2134 & 8 & 0.6844 & 48 \\
\hline 21 & Produk kertas dan percetakan & 1.0133 & 22 & 1.4243 & 8 \\
\hline 22 & Industri bahan kimia & 1.0305 & 21 & 0.8415 & 25 \\
\hline 23 & Cat dan lakuer & 1.1655 & 11 & 0.7559 & 38 \\
\hline 24 & Lain-lain produk bahan kimia & 0.8957 & 37 & 0.7893 & 33 \\
\hline 25 & Petroleum dan arang batu & 1.2496 & 7 & 0.6640 & 51 \\
\hline 26 & Getah diproses & 1.1275 & 16 & 0.6286 & 56 \\
\hline 27 & Produk getah & 1.0492 & 19 & 0.7749 & 35 \\
\hline 28 & Produk plastik & 1.1917 & 9 & 0.6350 & 55 \\
\hline 29 & Industri gelas dan kaca & 0.9103 & 36 & 0.8107 & 32 \\
\hline 30 & Simen, kapur dan plaster & 1.1558 & 14 & 0.6560 & 52 \\
\hline 31 & Bahan mineral bukan logam & 1.2816 & 5 & 0.7570 & 37 \\
\hline 32 & Industri struktur logam & 1.1528 & 15 & 0.8653 & 24 \\
\hline 33 & Produk industri logam lain & 0.8881 & 38 & 0.7771 & 34 \\
\hline 34 & Peralatan berasaskan elektronik & 0.9936 & 26 & 0.7445 & 40 \\
\hline 35 & Peralatan berasaskan elektrik & 0.8404 & 43 & 1.4655 & 7 \\
\hline 36 & Kenderaan bermotor & 1.0845 & 18 & 2.1059 & 3 \\
\hline 37 & $\begin{array}{l}\text { Kelengkapan pengangkutan } \\
\text { yang lain }\end{array}$ & 1.0943 & 17 & 0.8205 & 31 \\
\hline 38 & Produk pembuatan yang lain & 0.8760 & 39 & 0.7146 & 44 \\
\hline 39 & Elektrik dan gas & 0.8661 & 40 & 1.2597 & 11 \\
\hline 40 & Air & 0.6594 & 58 & 0.6908 & 47 \\
\hline 41 & Bangunan dan pembinaan & 0.7702 & 53 & 0.8212 & 30 \\
\hline 42 & Perdagangan borong dan runcit & 0.7861 & 52 & 1.2592 & 12 \\
\hline 43 & Hotel dan restoran & 0.7240 & 54 & 0.8341 & 27 \\
\hline 44 & Pengangkutan & 1.0043 & 25 & 1.4190 & 9 \\
\hline
\end{tabular}


Lampiran 1 (sambungan)

\begin{tabular}{lllcrcc}
\hline \multirow{2}{*}{ Industri } & \multicolumn{2}{c}{ Kaitan ke belakang } & & \multicolumn{2}{c}{ Kaitan ke hadapan } \\
\cline { 6 - 7 } \cline { 5 - 6 } & \multicolumn{2}{c}{ Indeks } & Kedudukan & & Indeks & Kedudukan \\
\hline 45 & Komunikasi & 0.7971 & 50 & & 0.9667 & 19 \\
46 & Perkhidmatan bank & 0.9539 & 29 & & 0.7630 & 36 \\
47 & Insurans & 0.9348 & 31 & & 0.8215 & 29 \\
48 & Hartanah dan hak milik rumah & 1.0408 & 20 & & 1.0465 & 16 \\
49 & Perkhidmatan perniagaan & 0.6681 & 57 & & 0.9929 & 17 \\
50 & Pendidikan swasta & 0.8070 & 47 & & 1.2051 & 14 \\
51 & Kesihatan swasta & 0.8060 & 48 & & 0.8846 & 23 \\
52 & Rekreasi dan kebudayaan & 0.6778 & 56 & & 0.8377 & 26 \\
53 & Penyelenggaraan motor & 0.9277 & 33 & & 0.6236 & 57 \\
54 & Penyelenggaraan lain dan & 0.7928 & 51 & & 0.6517 & 53 \\
& pembersihan & & & & \\
55 & Perkhidmatan awam dan & 0.9449 & 30 & & 2.0360 & 4 \\
& pertahanan & & & & \\
56 & Pentadbiran awam lain & 0.9208 & 34 & & 0.9773 & 18 \\
57 & Institusi bukan untung swasta & 0.9332 & 32 & & 0.6205 & 58 \\
58 & Perkhidmatan swasta lain & 0.6939 & 55 & & 0.7109 & 45 \\
\hline
\end{tabular}

28 IJMS 16 (1), 1-30 (2009) 


\section{Lampiran 2}

Aliran penawaran dan permintaan di dalam sesebuah jadual inputoutput dapat diwakilkan berdasarkan persamaan (A1) dan (A2) berikut:

$$
\begin{gathered}
X_{1}=x_{11}+x_{21}+x_{\mathrm{n} 1}+V_{1} \\
X_{2}=x_{12}+x_{22}+x_{\mathrm{n} 2}+V_{2} \\
\dot{\cdot} \cdot \vec{\cdot} \cdot \dot{\cdot} \cdot \dot{x}_{\mathrm{n} 3}+\dot{x}_{23}+\dot{x}_{\mathrm{n} 3}
\end{gathered}
$$

di mana $X$ ialah output industri, $x_{i i}$ ialah aliran output daripada industri $j$ kepada industri $i$ (input perantaraan) dan $V$ adalah input primer. Aliran permintaan pula diwakilkan seperti persamaan berikut;

$$
\begin{aligned}
& X_{1}=x_{11}+x_{12}+x_{13}+F_{1} \\
& X_{2}=x_{21}+x_{22}+x_{23}+F_{2} \\
& \dot{\cdot}=\dot{x}_{\mathrm{n} 1}+\dot{x}_{\mathrm{n} 2}+\dot{x}_{\mathrm{n} 3}+\dot{F}_{\mathrm{n}}
\end{aligned}
$$

di mana $x_{i j}$ dan $F$ masing-masing ialah aliran output daripada industri $i$ kepada industri $j$ (permintaan perantaraan) dan permintaan akhir.

Kaitan ke belakang dan ke hadapan dapat dikira berdasarkan persamaan berikut;

Kaitan ke belakang

$\sum_{i} \mathrm{U}_{i j}=\left[(1 / \mathrm{n}) \sum_{i} \mathrm{~b}_{i j} /\left(1 / \mathrm{n}^{2}\right) \sum_{i} \sum_{j} \mathrm{~b}_{i j}\right]$

Di mana $n$ ialah jumlah bilangan industri dalam ekonomi, $\sum_{i} b_{i j}$ adalah jumlah lajur pekali matrik songsang Leontief dan $\sum_{i} \sum_{j} b_{i j}$ adalah jumlah keseluruhan nilai pekali matrik songsang Leontief.

Kaitan ke hadapan

$\sum_{j} \mathrm{U}_{i j}=\left[(1 / \mathrm{n}) \sum_{j} \mathrm{~b}_{i j} /\left(1 / \mathrm{n}^{2}\right) \sum_{i} \sum_{j} \mathrm{~b}_{i j}\right]$

Di mana $\sum_{j} \mathrm{~b}_{i j}$ adalah jumlah baris pekali matrik songsang Leontief. Matrik songsang Leontief $(I-A)^{-1}$ boleh dikira dengan menggunakan persamaan berikut: 
$X=A X+F$

$X-A X=F$

$(I-A) X=F$

$X=(I-A)^{-1} F$

di mana $I$ ialah matrik identiti dan $A$ ialah matrik pekali input. Matrik $A$ diperolehi dengan membahagikan aliran input setiap industri $\left(x_{i, j}\right)$ dengan jumlah input $\left(X_{j}\right)$ bagi industri tersebut. 